\title{
PRIORITAS PEMBANGUNAN JEMBATAN DI KABUPATEN ACEH BESAR
}

\author{
E. Saputra ${ }^{1)}$, R. Anggraini ${ }^{2)}$, Muttaqin ${ }^{3)}$ \\ Magister Teknik Sipil, Universitas Syiah Kuala, Banda Aceh \\ Email: $\underline{\text { edi1213saputra@gmail.com }}{ }^{1)}$, renni.anggraini@gmail.com ${ }^{2)}$ \\ muttaqin@unsyiah.ac.id ${ }^{3)}$
}

DOI: http://dx.doi.org/10.29103/tj.v11i1.424

(Received: December 2020 / Revised: January 2021 / Accepted: January 2021)

\begin{abstract}
Abstrak
Pemerintah Kabupaten Aceh Besar telah mengusulkan pembangunan jembatan ke Kementerian Pekerjaan Umum dan Perumahan Rakyat (PUPR) sebanyak 5 ruas untuk dibangun pada tahun 2021. Usulan pembangunan jembatan tersebut di tahun 2021 tidak dapat dibangun semua, karena adanya keterbatasan anggaran. Oleh karena itu 5 ruas pembangunan jembatan yang diusulkan, perlu ditentukan skala prioritas. Penelitian ini bertujuan untuk menganalisis kriteria yang dominan perlu dipertimbangkan dalam pembangunan jembatan dan menganalisis prioritas pembangunan jembatan di Kabupaten Aceh Besar. Penelitian ini menggunakan metode kuantitatif melalui kuesioner. Teknik analisis data digunakan Analytical Hierarchy Process (AHP). Hasil penelitian menunjukkan bahwa kriteria yang dominan perlu dipertimbangkan dalam pembangunan jembatan adalah kriteria ekonomis dengan nilai rata-rata gabungan eigen sebesar 0,35. Prioritas pembangunan jembatan adalah Jembatan Kr. Keumeuruek sebagai prioritas 1 dengan bobot sebesar 0,46, Jembatan Siron II dan Jembatan Blang Baro I sebagai prioritas 2 dengan bobot sama-sama sebesar 0,20, serta Jembatan Alue Jeumpung dan Jembatan Inong Balee sebagai prioritas 3 dengan bobot sama-sama sebesar 0,07.
\end{abstract}

Kata kunci: prioritas, pembangunan, jembatan, kriteria, alternatif

\begin{abstract}
The Aceh Besar District Government has proposed building a bridge to the Ministry of Public Works and Public Housing (PUPR) as many as 5 sections to be built in 2021. The proposed bridge construction in 2021 cannot all be built, due to budget constraints. Therefore, the 5 proposed bridge construction sections need to determine the priority scale. This study aims to analyze the dominant criteria that need to be considered in bridge construction and to analyze the priority of bridge construction in Aceh Besar District. This study uses a quantitative method through a questionnaire. The data analysis technique used is Analytical Hierarchy Process (AHP). The results showed that the dominant criterion that needs to be considered in the construction of a bridge is an economic criterion with an average combined eigenvalue of 0.35 . The bridge construction priority is the $\mathrm{Kr}$ Bridge. Keumeuruek as priority 1 with a weight of 0.46, Siron II Bridge and Blang Baro I Bridge as priority 2 with equal weight of 0.20 , and Alue Jeumpung Bridge and Inong Balee Bridge as priority 3 with equal weights of 0,07 .
\end{abstract}

Keywords: priority, development, bridges, criteria, alternatives 


\section{Latar Belakang}

Jembatan adalah bangunan pelengkap jalan yang menghubungkan suatu lintasan yang terputus akibat suatu rintangan, melintasi obyek topografi atau adanya penyebab lainnya, dengan cara melompati rintangan tersebut tanpa menimbulkan atau menutup rintangan itu. Lintasan tersebut bisa merupakan jalan kendaraan, jalan kereta api atau jalan pejalan kaki, sedangkan rintangan tersebut dapat berupa sungai, jalan, jalan kereta api, atau jurang (Sasongko, 2018). Peranan jembatan pada hakikatnya menyangkut hajat hidup orang banyak, memacu pertumbuhan ekonomi suatu wilayah, menyeimbangkan pengembangan antar daerah, mengendalikan struktur pengembangan wilayah pada tingkat nasional, serta meningkatkan pertahanan dan keamanan negara. Oleh karena itu pembangunan jembatan dapat mewujudkan masyarakat Indonesia yang adil dan makmur berdasarkan Pancasila dan Undang-undang Dasar 1945. Sehubungan pentingnya peranan jembatan, maka Pemerintah Daerah Kabupaten Aceh Besar perlu melakukan kegiatan pembangunan jembatan di wilayah administrasinya.

Dana Alokasi Khusus (DAK) adalah dana yang dialokasikan kepada daerah tertentu berdasarkan usulan daerah yang berisi usulan-usulan kegiatan dan sumber-sumber pembiayaannya diajukan kepada meteri teknis oleh daerah tersebut (Amin, 2019). Menurut data rencana usulan kegiatan DAK tahun 2020, Pemerintah Kabupaten Aceh Besar telah mengusulkan pembangunan jembatan ke Kementerian Pekerjaan Umum dan Perumahan Rakyat (PUPR) Republik Indonesia sebanyak 5 ruas untuk dibangun pada tahun 2021. Kegiatan pembangunan diusulkan pada ruas Jembatan Blang Baro I, Inong Balee, Siron II, Kr. Keumeuruek, dan Jembatan Alue Jeumpung. Adapun jumlah total biaya pembangunan jembatan tersebut adalah sebesar Rp. 69.175.000.000 (enam puluh sembilan milyar seratus tujuh puluh lima juta rupiah).

Usulan pembangunan jembatan tersebut di tahun 2021 tidak dapat dibangun semua, karena adanya keterbatasan anggaran. Keterbatasan anggaran disebabkan oleh adanya refocusing anggaran untuk penanganan Corona Virus Disease 2019 (Covid 19) di seluruh wilayah Indonesia. Implikasi dari adanya refocusing tersebut adalah biaya pembangunan jembatan untuk tahun 2021 di Kabupaten Aceh Besar hanya dapat dialokasi sebesar Rp. 11.919.262.000 (sebelas milyar sembilan ratus sembilan belas juta dua ratus enam puluh dua ribu rupiah) (Direktorat Jenderal Perimbangan Keuangan, 2020). Oleh karena itu 5 ruas pembangunan jembatan yang diusulkan, perlu ditentukan skala prioritas guna melihat ruas jembatan mana yang paling penting ditingkatkan demi kepentingan publik untuk tahun 2021.

Skala prioritas adalah proses pertimbangan berbagai kriteria dalam menentukan sebuah keputusan. Beberapa kriteria yang perlu dipertimbangkan adalah kriteria teknis, ekonomis, tata guna lahan, aksesibilitas, pengembangan wilayah, kependudukan, dan fasilitas sosial. Setiap kriteria tersebut mempunyai karakteristik yang berbeda-beda pada setiap lokasi pembangunan jembatan yang diusulkan. Oleh karena itu dengan mempertimbangkan beberapa kriteria tersebut, maka dapat ditentukan skala prioritas melalui penggunaan metode Analytical Hierarchy Process (AHP). AHP adalah analisis yang mampu mengambil keputusan dengan mempertimbangkan seluruh kriteria yang ada sekompreherensif mungkin dalam penentuan prioritas. Sehubungan dengan hal tersebut, maka perlu dilakukan penelitian tentang "Penentuan Prioritas Pembangunan Jembatan di 
Kabupaten Aceh Besar dengan Menggunakan Metode Analytical Hierarchy Process (AHP)". Kabupaten Aceh Besar dipilih sebagai studi kasus, karena berdasarkan penelitian terdahulu di wilayah Provinsi Aceh belum pernah ditinjau. Penelitian serupa yang pernah dilakukan di wilayah Provinsi Jawa Timur (Ompusunggu et al., 2009), (Sudradjat et al., 2015), Kalimantan Timur (Hendriyani et al., 2013), Kepulauan Bangka Belitung (Rakhmatika et al., 2017). Tujuan dari penelitian ini adalah menganalisis kriteria yang dominan perlu dipertimbangkan dalam pembangunan jembatan di Kabupaten Aceh Besar dan menganalisis urutan prioritas pembangunan jembatan di Kabupaten Aceh Besar.

\section{Metode Penelitian}

\subsection{Objek dan Lokasi Penelitian}

Objek dalam penelitian ini adalah jembatan yang tercantum di dalam rencana usulan Dana Alokasi Khusus (DAK) tahun 2020 di Kabupaten Aceh Besar. Pembangunan jembatan yang diusulkan terdapat sebanyak 5 ruas. Lokasi ruas jembatan tersebut diperlihatkan pada Tabel 1.

Tabel 1 Lokasi penelitian

\begin{tabular}{clc}
\hline No. & \multicolumn{1}{c}{ Pembangunan Jembatan } & Lokasi \\
\hline 1 & Jembatan Blang Baro I & Kecamatan Lembah Selawah \\
\hline 2 & Jembatan Inong Balee & Kecamatan Kota Jantho \\
\hline 3 & Jembatan Siron II & Kecamatan Kuta Cot Glie \\
\hline 4 & Jembatan Kr. Keumeuruek & Kecamatan Seulimeum \\
\hline 5 & Jembatan Alue Jeumpung & Kecamatan Kota Jantho \\
\hline
\end{tabular}

\subsection{Teknik Penentuan Sampel}

Pada dasarnya AHP dapat digunakan untuk mengolah data dari satu responden ahli. Namun demikian dalam aplikasinya penilaian kriteria dan alternatif dilakukan oleh beberapa ahli multi disiplioner. Konsekuensinya adalah pendapat beberapa ahli tersebut perlu dicek konsistensinya satu persatu. Pendapat yang konsisten kemudian digabungkan dengan menggunakan rata-rata (Marimin, 2004). Teknik penentuan sampel yang digunakan adalah purposive sampling. Purposive sampling adalah teknik pengambilan sampel dengan pertimbangan tertentu (Hermawan, 2019). Adapun pertimbangan dalam penelitian ini didasarkan pada pemangku kepentingan dan pengambil kebijakan (stakeholders) yang mengetahui kondisi kriteria pada lokasi usulan pembangunan jembatan di Kabupaten Aceh Besar. Jumlah sampel dalam penelitian ini ditetapkan sebanyak 7 stakeholders yaitu Kepala Bidang Bina Marga Dinas PUPR Kabupaten Aceh Besar, Kepala Bidang Program Pembangunan Daerah Badan Perencanaan Pembangunan Daerah (Bappeda) Kabupaten Aceh Besar, Anggota Komisi IV Bidang Pembangunan Dewan Perwakilan Rakyat Kabupaten (DPRK) Aceh Besar, Camat Lembah Seulawah, Camat Kota Jantho, Camat Kuta Cot Glie, dan Camat Seulimeum.

\subsection{Teknik Pengumpulan Data}

Kuesioner penelitian dirancang atas dua bagian, yaitu kuesioner bagian A dan kuesioner bagian B. Kuesioner bagian A menanyakan tentang perbandingan kriteria berpasangan, sedangkan kuesioner bagian B menanyakan tentang 
perbandingan alternatif berpasangan. Pengukuran jawaban kuesioner bagian A dan bagian B menggunakan skala Saaty yaitu penilaian perbandingan berpasangan. Pengumpulan data kuesioner dilakukan dengan menjumpai langsung tempat keberadaan responden dan memberikan formulir kuesioner. Responden diminta untuk memilih salah satu jawaban yang telah disediakan pada formulir kuesioner dengan memberikan checklist $(\sqrt{ })$.

\subsection{Teknik Analisis Data}

Analisis data ini menggunakan Analytical Hierarchy Process (AHP). AHP adalah suatu metode atau model untuk pendukung keputusan yang dikembangkan oleh Thomas L. Saaty. Model pendukung keputusan akan menguraikan suatu masalah dari multi kriteria yang kompleks untuk menjadi suatu hirarki. Hirarki didefinisikan sebagai suatu representasi dari sebuah permasalahan yang kompleks dalam stuktur multi level dimana level pertama adalah tujuan, yang diikuti level kriteria, hingga level alternatif (Alvioletta et al., 2020). Hirarki AHP meliputi tujuan, kriteria, dan alternatif. Tujuannya adalah untuk mengidentifikasi kriteria yang dominan perlu dipertimbangkan dalam pembangunan jembatan di Kabupaten Aceh Besar dan untuk menentukan urutan prioritas pembangunan jembatan di Kabupaten Aceh Besar. Kriterianya adalah meliputi kriteria teknis (K1), kriteria ekonomis (K2), kriteria tata guna lahan (K3), kriteria aksesibilitas (K4), kriteria pengembangan wilayah (K5), kriteria kependudukan (K6), dan kriteria fasilitas sosial (K7). Justifikasi peneliti terhadap kriteria tersebut adalah sebagai berikut:

1. Kriteria teknis (K1) yang ditinjau adalah panjang jembatan. Kriteria teknis ditinjau dengan pertimbangan lokasi usulan yang mempunyai panjang terendah perlu diprioritaskan pembangunan jembatan, sehingga ketersediaan anggaran sanggup mengakomodir pembangunan yang dimaksud.

2. Kriteria ekonomis (K2) yang ditinjau adalah biaya pembangunan jembatan. Kriteria ekonomis ditinjau dengan pertimbangan lokasi usulan yang mempunyai biaya terendah perlu diprioritaskan pembangunan jembatan, sehingga ketersediaan anggaran sanggup mengakomodir pembangunan yang dimaksud.

3. Kriteria tata guna lahan (K3) yang ditinjau adalah total kawasan pertanian, perkebunan, dan perikanan. Kriteria tata guna lahan ditinjau dengan pertimbangan lokasi usulan yang banyak melewati lahan produktif perlu diprioritaskan pembangunan jembatan, sehingga hasil bumi banyak dapat diangkut oleh masyarakat guna untuk ketahanan pangan.

4. Kriteria aksesibilitas (K4) yang ditinjau adalah jarak ke ibu kota kecamatan. Kriteria aksesibilitas ditinjau dengan pertimbangan lokasi usulan yang mempunyai jarak terdekat dengan ibu kota kecamatan perlu diprioritaskan pembangunan jembatan, sehingga dapat mempermudah masyarakat dalam melakukan berbagai aktivitas di pusat kecamatan.

5. Kriteria aksesibilitas (K5) yang ditinjau adalah desa kurang berkembang. Kriteria pengembangan wilayah ditinjau dengan pertimbangan lokasi usulan yang kurang berkembang perlu diprioritaskan pembangunan jembatan, sehingga dapat tercapainya pemerataan pembangunan sesuai amanat Undangundang Dasar 1945. 
6. Kriteria kependudukan (K6) yang ditinjau adalah jumlah penduduk. Kriteria kependudukan ditinjau dengan pertimbangan lokasi usulan yang mempunyai jumlah penduduk banyak perlu diprioritaskan pembangunan jembatan, sehingga hajat hidup orang banyak terhadap prasarana umum dapat tercapai.

7. Kriteria fasilitas sosial (K7) yang ditinjau adalah total fasilitas pendidikan, kesehatan, dan keagamaan. Kriteria fasilitas sosial ditinjau dengan pertimbangan lokasi usulan yang mempunyai atau melewati banyak fasilitas pendidikan, kesehatan, dan keagamaan perlu diprioritaskan pembangunan jembatan, sehingga masyarakat dapat mudah mengaksesnya.

Alternatifnya adalah meliputi Jembatan Blang Baro I (A1), Jembatan Inong Balee (A2), Jembatan Siron II (A3), Jembatan Kr. Keumeuruek (A4), dan Jembatan Jeumpung (A5). Tahapan AHP adalah sebagai berikut:

1. Membuat matriks perbandingan kriteria berpasangan

Matriks perbandingan kriteria berpasangan berguna untuk mendapatkan sejumlah ouput seperti nilai eigen kriteria, jumlah nilai eigen kriteria, nilai ratarata eigen kriteria, $\square$ maks kriteria, indeks konsistensi (CI) kriteria, dan rasio konsistensi (CR) kriteria. Output tersebut dihitung dengan cara sebagai berikut: a. Nilai eigen kriteria dihitung dengan cara nilai skala suatu kriteria dikali dengan jumlah nilai skala semua kriteria secara vertikal yang terdapat pada matriks perbandingan kriteria berpasangan.

b. Jumlah nilai eigen kriteria dihitung dengan cara menjumlahkan nilai eigen masing-masing kriteria secara horizontal.

c. Nilai rata-rata eigen kriteria dihitung dengan cara jumlah nilai eigen kriteria dibagi dengan jumlah kriteria.

d. $\square$ maks kriteria dihitung dengan cara jumlah nilai skala semua kriteria secara vertikal pada matriks perbandingan kriteria berpasangan dikali dengan nilai rata-rata eigen kriteria.

e. CI kriteria dihitung dengan cara hasil jumlah nilai $\square$ maks kriteria yang telah dikurangi jumlah kriteria, dibagi dengan hasil jumlah kriteria yang telah dikurangi 1 .

f. CR kriteria dihitung dengan cara nilai CI kriteria dibagi dengan Indeks Random (IR).

Setelah memastikan semua persepsi responden konsisten melalui CR, maka nilai rata-rata eigen kriteria yang telah diperoleh sebelumnya dapat digunakan dan dihitung nilai rata-rata gabungan eigen kriteria. Nilai rata-rata gabungan eigen kriteria dihitung dengan cara nilai rata-rata eigen kriteria antar responden dijumlahkan lalu dibagi dengan jumlah responden (7). Nilai rata-rata gabungan eigen kriteria tertinggi menunjukkan kriteria yang dominan perlu dipertimbangkan dalam pembangunan jembatan di Kabupaten Aceh Besar.

2. Membuat matriks perbandingan alternatif berpasangan Matriks perbandingan alternatif berpasangan berguna untuk mendapatkan sejumlah ouput seperti nilai eigen alternatif, jumlah nilai eigen alternatif, nilai rata-rata eigen alternatif, $\square$ maks alternatif, CI alternatif, dan CR alternatif. Output tersebut dihitung dengan cara seperti pada matriks perbandingan kriteria berpasangan yang telah diuraikan sebelumnya. Setelah memastikan semua persepsi responden konsisten melalui $\mathrm{CR}$, maka nilai rata-rata eigen alternatif yang telah diperoleh sebelumnya dapat digunakan dan dihitung nilai 
rata-rata gabungan eigen alternatif. Nilai rata-rata gabungan eigen alternatif dihitung dengan cara nilai rata-rata eigen alternatif antar responden dijumlahkan lalu dibagi dengan jumlah responden (7).

3. Menentukan urutan prioritas alternatif

Penentuan urutan prioritas dilakukan dengan cara mengalikan nilai rata-rata gabungan eigen dari matriks perbandingan kriteria berpasangan dengan nilai rata-rata gabungan eigen dari matriks perbandingan alternatif berpasangan. Hasil perkalian nilai rata-rata gabungan eigen antar matriks tersebut, yang tertinggi hingga terendah menunjukkan ruas jembatan yang menjadi urutan prioritas pembangunan di Kabupaten Aceh Besar.

\section{Hasil dan Pembahasan}

\subsection{Matriks Perbandingan Kriteria Berpasangan}

Matriks perbandingan kriteria berpasangan bertujuan untuk memetakan nilai skala dari persepsi responden terhadap kriteria yang perlu dipertimbangkan dalam pembangunan jembatan di Kabupaten Aceh Besar. Perletakan nilai skala pada matriks perbandingan kriteria berpasangan dilakukan berdasarkan persepsi responden. Dalam hal ini seluruh persepsi responden mempunyai nilai CR kriteria $<0,1$, sehingga seluruh persepsi responden dinyatakan konsisten dalam memberikan penilaian tingkat kepentingan antar kriteria. Sehubungan dengan konsitennya persepsi responden, maka berikut ini dapat diperlihatkan nilai ratarata gabungan eigen kriteria dari seluruh responden yang dapat dilihat pada Gambar 1.

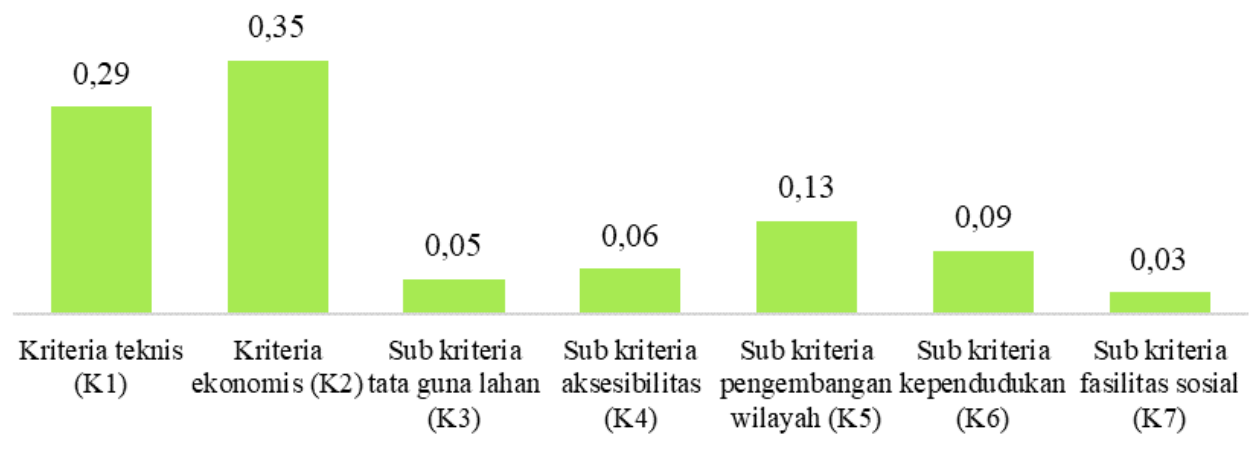

Gambar 1 Nilai rata-rata gabungan eigen kriteria

Gambar 1 memperlihatkan bahwa nilai rata-rata gabungan eigen kriteria tertinggi didapat pada kriteria ekonomis sebesar 0,35. Hal ini berarti bahwa kriteria yang dominan perlu dipertimbangkan dalam pembangunan jembatan di Kabupaten Aceh Besar menurut persepsi stakeholders adalah kriteria ekonomis. Selain kriteria ekonomis, kriteria lainnya yang perlu dipertimbangkan dalam pembangunan jembatan di Kabupaten Aceh Besar menurut persepsi stakeholders adalah kriteria teknis dengan nilai rata-rata gabungan eigen kriteria sebesar 0,29, sub kriteria pengembangan wilayah dengan nilai rata-rata gabungan eigen kriteria sebesar 0,13, sub kriteria kependudukan dengan nilai rata-rata gabungan eigen kriteria sebesar 0,09, sub kriteria aksesibilitas dengan nilai rata-rata gabungan eigen kriteria sebesar 0,06 , sub kriteria tata guna lahan dengan nilai rata-rata gabungan eigen kriteria sebesar 0,05 , dan sub kriteria fasilitas sosial dengan nilai rata-rata gabungan eigen kriteria sebesar 0,06 .

Prioritas Pembangunan Jembatan di Kabupaten Aceh Besar - E. Saputra, R. Anggraini, Muttaqin 
Hasil penelitian ini terdapat perbedaan dengan 3 penelitian terdahulu. Kriteria yang dominan perlu dipertimbangkan dalam pembangunan Jembatan Penajam-Balikpapan adalah kriteria aksesibilitas dengan bobot sebesar 0,24 (Hendriyani et al., 2013). Kriteria yang dominan perlu dipertimbangkan dalam penanganan jembatan pada Jaringan Jalan Provinsi Jawa Timur adalah kriteria kondisi jembatan dengan bobot sebesar 37,93\% (Sudradjat et al., 2015). Kriteria yang dominan perlu dipertimbangkan dalam pemeliharaan jembatan ruas jalan nasional di Pulau Bangka adalah kriteria kondisi umum jembatan dengan bobot sebesar 0,37 (Rakhmatika et al., 2017). Hasil penelitian ini terdapat persamaan dengan 1 penelitian terdahulu. Kriteria yang dominan perlu dipertimbangkan dalam pemeliharaan jembatan di Jalan Pantura adalah kriteria budget dengan bobot sebesar 0,42 (Ompusunggu et al., 2009).

\subsection{Matriks Perbandingan Altenatif Berpasangan}

Matriks perbandingan alternatif berpasangan bertujuan untuk memetakan nilai skala dari persepsi responden terhadap alternatif pembangunan jembatan di Kabupaten Aceh Besar pada masing-masing kriteria. Dalam hal ini seluruh persepsi responden mempunyai nilai CR alternatif pada masing-masing kriteria < 0,1 , sehingga seluruh persepsi responden dinyatakan konsisten dalam memberikan penilaian tingkat kepentingan antar alternatif. Sehubungan dengan konsitennya persepsi responden, maka berikut ini dapat diperlihatkan nilai rata-rata gabungan eigen alternatif dari seluruh responden yang dapat dilihat pada Gambar 2.

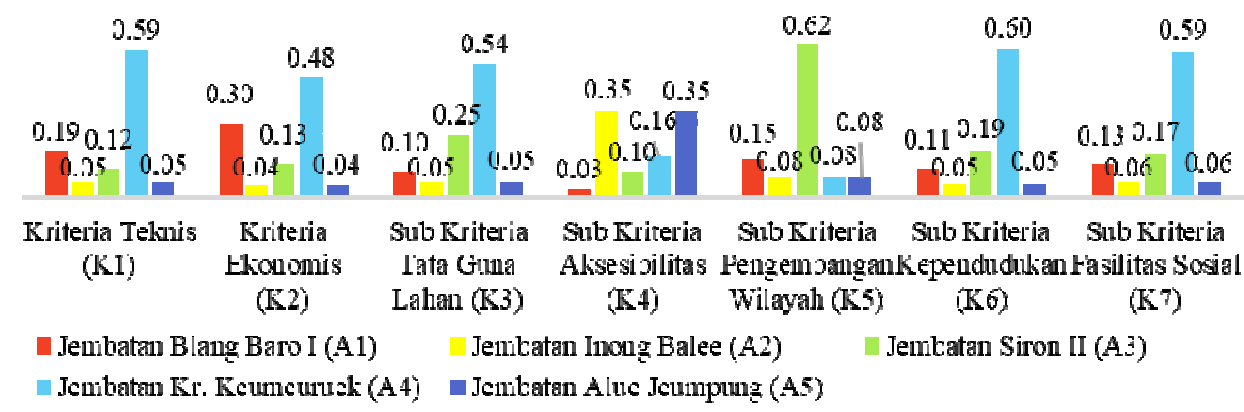

Gambar 2 Nilai rata-rata gabungan eigen alternatif pada masing-masing kriteria

Gambar 2 memperlihatkan bahwa bila dilihat dari kriteria teknis, ekonomis, sub kriteria tata guna lahan, sub kriteria kependudukan, dan sub kriteria fasilitas sosial, pembangunan jembatan yang perlu diprioritaskan adalah Jembatan Kr. Keumeuruek. Bila dilihat dari sub kriteria aksesibilitas, pembangunan jembatan yang perlu diprioritaskan adalah Jembatan Inong Balee. Bila dilihat dari sub kriteria pengembangan wilayah, pembangunan jembatan yang perlu diprioritaskan adalah Jembatan Siron II.

\subsection{Urutan Prioritas Alternatif}

Sehubungan matriks perbandingan kriteria berpasangan dan matriks perbandingan alternatif berpasangan pada masing-masing kriteria telah dibuat, maka selanjutnya dapat menentukan prioritas alternatif pembangunan jembatan di Kabupaten Aceh Besar. Penentuan prioritas alternatif akan mengakomodir seluruh kriteria yang ditinjau. Penentuan urutan prioritas dilakukan dengan cara 
mengalikan nilai rata-rata gabungan eigen kriteria dengan nilai rata-rata gabungan eigen alternatif pada masing-masing kriteria. Hasil perkalian antar nilai rata-rata gabungan eigen (bobot) yang tertinggi hingga terendah menunjukkan ruas jembatan yang menjadi urutan prioritas pembangunan di Kabupaten Aceh Besar. Adapun urutan prioritas alternatif pembangunan jembatan diperlihatkan pada Tabel 2.

Tabel 2 Urutan prioritas alternatif

\begin{tabular}{|c|c|c|c|}
\hline \multirow{3}{*}{ Kriteria } & $\begin{array}{c}\text { Nilai Rata-rata Gabungan } \\
\text { Eigen Kriteria }\end{array}$ & $\begin{array}{c}\text { Hasil } \\
\text { Perkalian }\end{array}$ & \multirow{5}{*}{$\begin{array}{c}\text { Prioritas } \\
\text { Alternatif }\end{array}$} \\
\hline & $\begin{array}{lllllll}\text { K1 } & \text { K2 } & \text { K3 } & \text { K4 } & \text { K5 } & \text { K6 } & \text { K7 } \\
\end{array}$ & Antar & \\
\hline & $0,290,350,050,060,130,090,03$ & Nilai & \\
\hline \multirow[t]{2}{*}{ Alternatif } & $\begin{array}{c}\text { Nilai Rata-rata Gabungan } \\
\text { Eigen Alternatif }\end{array}$ & $\begin{array}{l}\text { Rata-rata } \\
\text { Gabungan }\end{array}$ & \\
\hline & $\begin{array}{lllllll}\text { K1 } & \text { K2 } & \text { K3 } & \text { K4 } & \text { K5 } & \text { K6 } & \text { K7 }\end{array}$ & Eigen & \\
\hline Jembatan Blang Baro I & $\begin{array}{lllllll}0,19 & 0,30 & 0,10 & 0,03 & 0,15 & 0,11 & 0,13\end{array}$ & 0,20 & 2 \\
\hline Jembatan Inong Balee & $\begin{array}{lllllllll}0,05 & 0,04 & 0,05 & 0,35 & 0,08 & 0,05 & 0,06\end{array}$ & 0,07 & 3 \\
\hline Jembatan Siron II & $\begin{array}{llllllll}0,12 & 0,13 & 0,25 & 0,10 & 0,62 & 0,19 & 0,17\end{array}$ & 0,20 & 2 \\
\hline Jembatan Kr. Keumeuruek & $\begin{array}{lllllll}0,59 & 0,48 & 0,54 & 0,16 & 0,08 & 0,60 & 0,57\end{array}$ & 0,46 & 1 \\
\hline Jembatan Alue Jeumpung & $0,05 \quad 0,040,05 \quad 0,350,08 \quad 0,050,06$ & 0,07 & 3 \\
\hline Jumlah & & 1,00 & \\
\hline
\end{tabular}

Tabel 2 memperlihatkan bahwa urutan prioritas pembangunan jembatan di Kabupaten Aceh Besar dari seluruh persepsi stakeholders adalah Jembatan $\mathrm{Kr}$. Keumeuruek sebagai prioritas 1 dengan bobot sebesar 0,46, Jembatan Siron II dan Jembatan Blang Baro I sebagai prioritas 2 dengan bobot sama-sama sebesar 0,20, serta Jembatan Alue Jeumpung dan Jembatan Inong Balee sebagai prioritas 3 dengan bobot sama-sama sebesar 0,07. Sehubungan dengan penetapan prioritas tersebut, maka selanjutnya perlu menentukan batas prioritas ke berapa dapat dilakukan pembangunan jembatan di Kabupaten Aceh Besar. Penentuan batas prioritas perlu ditetapkan karena total biaya pembangunan jembatan seluruh alternatif sebesar Rp. 69.175.000.000 (enam puluh sembilan milyar seratus tujuh puluh lima juta rupiah), sudah direfocusing oleh Pemerintah Pusat menjadi sebesar Rp. 11.919.262.000 (sebelas milyar sembilan ratus sembilan belas juta dua ratus enam puluh dua ribu rupiah). Oleh karena itu penentuan batas prioritas ditetapkan dengan memilih beberapa alternatif yang mempunyai total biaya pembangunan tidak melebihi total anggaran yang sudah direfocusing. Adapun pemilihan batas prioritas pembangunan jembatan ini diperlihatkan pada Tabel 3.

Tabel 3 Pemilihan batas prioritas pembangunan jembatan

\begin{tabular}{cccccc}
\hline No. & Alternatif & Panjang & $\begin{array}{c}\text { Biaya } \\
\text { Pembangunan }\end{array}$ & $\begin{array}{c}\text { Prio } \\
\text { ritas }\end{array}$ & $\begin{array}{c}\text { Pemilihan } \\
\text { Prioritas }\end{array}$ \\
\hline 1 & Jembatan Blang Baro I (A1) & $45 \mathrm{~m}$ & Rp. 9.000.000.000 & 2 & Tidak Dipilih \\
\hline 2 & Jembatan Inong Balee (A2) & $60 \mathrm{~m}$ & Rp. 20.400.000.000 & 3 & Tidak Dipilih \\
\hline 3 & Jembatan Siron II (A3) & $50 \mathrm{~m}$ & Rp. 14.000.000.000 & 2 & Tidak Dipilih \\
\hline 4 & Jembatan Kr. Keumeuruek (A4) & $21,5 \mathrm{~m}$ & Rp. 5.375.000.000 & 1 & Dipilih \\
\hline 5 & Jembatan Alue Jeumpung (A5) & $60 \mathrm{~m}$ & Rp. 20.400.000.000 & 3 & Tidak Dipilih \\
\hline Jumlah & $237 \mathrm{~m}$ & Rp. 69.175.000.000 & & \\
\hline
\end{tabular}


Tabel 3 menunjukkan bahwa pembangunan jembatan di Kabupaten Aceh Besar hanya dapat dipilih 1 alternatif yaitu Jembatan Kr. Keumeuruek yang masuk dalam prioritas 1 sepanjang 21,5 m. Alternatif tersebut dipilih karena biaya pembangunan jembatan tidak melebihi total anggaran yang sudah direfocusing yaitu sebesar Rp. 11.919.262.000 (sebelas milyar sembilan ratus sembilan belas juta dua ratus enam puluh dua ribu rupiah). Adapun alternatif Jembatan Kr. Keumeuruek sebagai prioritas 1 mempunyai biaya pembangunan sebesar Rp. 5.375.000.000 (lima milyar tiga ratus tujuh puluh lima juta rupiah). Sementara, sisa biaya dari Rp. 11.919.262.000 (sebelas milyar sembilan ratus sembilan belas juta dua ratus enam puluh dua ribu rupiah) yaitu sebesar Rp. 6.544.262.000 (enam milyar lima ratus empat puluh empat juta dua ratus enam puluh dua ribu rupiah) dapat dialokasikan untuk penanganan jalan di Kabupaten Aceh Besar yang mencakup pemeliharaan jalan, peningkatan jalan, dan konstruksi baru.

\section{Kesimpulan dan Saran}

\subsection{Kesimpulan}

Kriteria yang dominan perlu dipertimbangkan dalam pembangunan jembatan di Kabupaten Aceh Besar adalah kriteria ekonomis dengan nilai rata-rata gabungan eigen sebesar 0,35. Urutan prioritas pembangunan jembatan di Kabupaten Aceh Besar adalah Jembatan Kr. Keumeuruek sebagai prioritas 1 dengan bobot sebesar 0,46, Jembatan Siron II dan Jembatan Blang Baro I sebagai prioritas 2 dengan bobot sama-sama sebesar 0,20, serta Jembatan Alue Jeumpung dan Jembatan Inong Balee sebagai prioritas 3 dengan bobot sama-sama sebesar 0,07 .

\subsection{Saran}

Disarankan Pemerintah Kabupaten Aceh Besar selain mempertimbangkan kriteria ekonomis, juga perlu mempertimbangkan kriteria lainnya seperti kriteria teknis, sub kriteria pengembangan wilayah, sub kriteria kependudukan, sub kriteria aksesibilitas, sub kriteria tata guna lahan, dan sub kriteria fasilitas sosial agar pembangunan jembatan tepat sasaran. Disarankan Pemerintah Kabupaten Aceh Besar dapat memprioritaskan jembatan Kr. Keumeuruek pada tahun 2021 ini diantara jembatan lainnya, agar biaya yang dibutuhkan sesuai dengan yang telah direfocusing oleh pemerintah pusat.

\section{Daftar Kepustakaan}

Alvioletta, V., Setyawan, M.Y.H., Saputra, M.H.K., 2020. Penerapan Metode Analytical Hierarchy Process (AHP) pada Penialaian Kepuasan Pelanggan Berdasarkan Pelayanan Divisi (Studi Kasus: CV Tirta Kencana). Kreatif Industri Nusantara, Bandung.

Amin, F., 2019. Penganggaran di Pemerintah Daerah. Universitas Brawijaya Press, Malang. 
Direktorat Jenderal Perimbangan Keuangan, K.K., 2020. Rincian Dana Alokasi Khusus (DAK) Fisik Tahun Anggaran 2021 Menurut Provinsi/Kabupaten/Kota.

Hendriyani, I., Wardhana, H., Hapsari, R., 2013. Kajian Alternatif Pembangunan Jembatan Penajam-Balikpapan. J. Teknol. Berkelanjutan (Sustainable Technol. Journal) 2, 6-20.

Hermawan, I., 2019. Metodologi Penelitian Pendidikan (Kuantitatif, Kualitatif \& Mixed Methode). Hidayatul Quran Kuningan, Kuningan.

Marimin, 2004. Teknik dan Aplikasi Pengambilan Keputusan Kriteria Majemuk. Grasindo, Jakarta.

Ompusunggu, A., Diputro, S.H., Haryono, 2009. Jurnal 2009 - Pemodelan Penentuan Skala Prioritas Pemeliharaan Jembatan di Jalan Pantura Jawa Timur. Pros. Semin. Nas. Manaj. Teknol. X 1-6.

Rakhmatika, Setiadji, B.H., Riyanto, B., 2017. Penentuan Urutan Prioritas Penanganan Pemeliharaan Jembatan Ruas Jalan Nasional di Pulau Bangka Provinsi Kepulauan Bangka Belitung 23, 38-47.

Sasongko, R., 2018. Survey Rekayasa Konstruksi. Polinema Press, Malang.

Sudradjat, H., Djakfar, L., Zaika, Y., 2015. Penentuan Prioritas Penanganan Jembatan pada Jaringan Jalan Provinsi Jawa Timur. Rekayasa Sipil 9, 219228. 